\title{
Women of the lesser nobility
}

N 1180 BERTRAm, the chamberlain of Earl Hugh II of Chester, married Mabel, the heiress of William Flamenc, and by grant of charter received her inheritance. Little is known of the origins of Bertram, and likewise the descent of Mabel's inheritance, from the time of Robert of Rhuddlan, who held the manor of Great Meols in 1066, is also obscure. ${ }^{1}$ What is clear, however, is that Bertram's service in his lord's household as chamberlain was rewarded with marriage to an heiress. Earl Hugh was here evidently exercising his right of marriage of the heiress of a tenant to reward a retainer in a way which facilitated his social mobility; what is made of Mabel's position is less clear. However, these are well worn themes. Bertram received only lands assessed at the value of one-fifth of a knight's fee. It is striking that, despite their relative obscurity, both Bertram and Mabel as landholders issued their own charters. Circa 1195-1200 Bertram and Mabel issued a joint charter on the occasion of the marriage of their daughter Alice with William fitz Bernard, granting three bovates of land as her marriage portion. ${ }^{2}$ Of even greater significance, however, is the fact that this charter was sealed with two seals. The seal appended on the left of the charter, which is possibly that of Bertram, depicts a unicorn and is considerably smaller than the seal on the right. The other seal is possibly that of Mabel, since it is of similar dimensions to her extant seal, a specimen of which authenticates a charter granted by Mabel, and is similar to that affixed to the joint grant made with Bertram. Further, both charters have the same witness list, so they were probably issued on the same occasion. Mabel's seal is round, of green wax, and depicts an ornate stylised fleur-de-lys. ${ }^{3}$ The lands concerned were of Mabel's inheritance, so it was Mabel's position as heiress which gave her the right to alienate them, and she did so to benefit her daughter. It is unlikely that Mabel would go to the effort of commissioning a seal 
die just for one document, so it is likely that she granted more charters to authenticate other documents, now lost, concerning her patrimonial lands.

A central problem for the study of lesser noblewomen's roles is the fragmentary nature of the evidence. This can partly be resolved where sequential or near-sequential copies of charters by the same grantors or their family exist. This chapter discusses female patronage of St Mary's, Clerkenwell, by the Munteni family in the second half of the twelfth century and shows how land tenure and kin connections could underpin active female patronage over two generations. It also assesses the interactions of the female life cycle and social status upon the participation of wives and widows in land transfers. Finally, the discussion of female lesser nobility will be extended to include examples of noblewomen who exerted power more formally, perhaps as public office holders. In so doing a wider context for discussion of noblewomen and power will be drawn. The evidence, although far from being comprehensive, shows how the roles of lesser noblewomen could resemble those of women of higher status.

Compiled in the first half of the thirteenth century, the cartulary of St Mary Clerkenwell is a rich source because it contains a large number of grants which involved women as witnesses, alienors and consentors. The priory of St Mary was a house of Augustinian canonesses founded c. 1145 on the inherited land of Muriel de Muteni, wife of Jordan Brisset, which eventually grew to become the twelfth richest nunnery at the Dissolution. ${ }^{4}$ Jordan and Muriel had four daughters, Lecia, Matilda, Emma and Roesia, who were all involved in the patronage of St Mary's. Muriel de Munteni and her daughter Lecia were particularly active in their support for the priory. There are charters of both in favour of Clerkenwell as wives and as widows; they thus acted to exert influence in similar contexts to women of the high nobility. ${ }^{5}$

Muriel de Munteni was married twice, firstly to Jordan de Brisset and secondly to Maurice, son of Robert de Totham. She carried her interest in Clerkenwell through both her marriages. There are twentythree documents in the cartulary which show the various ways that Muriel directly participated in religious patronage as grantor, cograntor with her husband, consentor and as a witness. ${ }^{6}$ It is worth considering her role in detail, since this will clarify the contexts of her activity and thus the importance of family connections and the impact of the female life cycle upon her participation. In 1152-62 Jordan and Muriel confirmed various gifts of tenants to Clerkenwell for the sake of their souls, their heirs, their friends and parents. The witness list has 


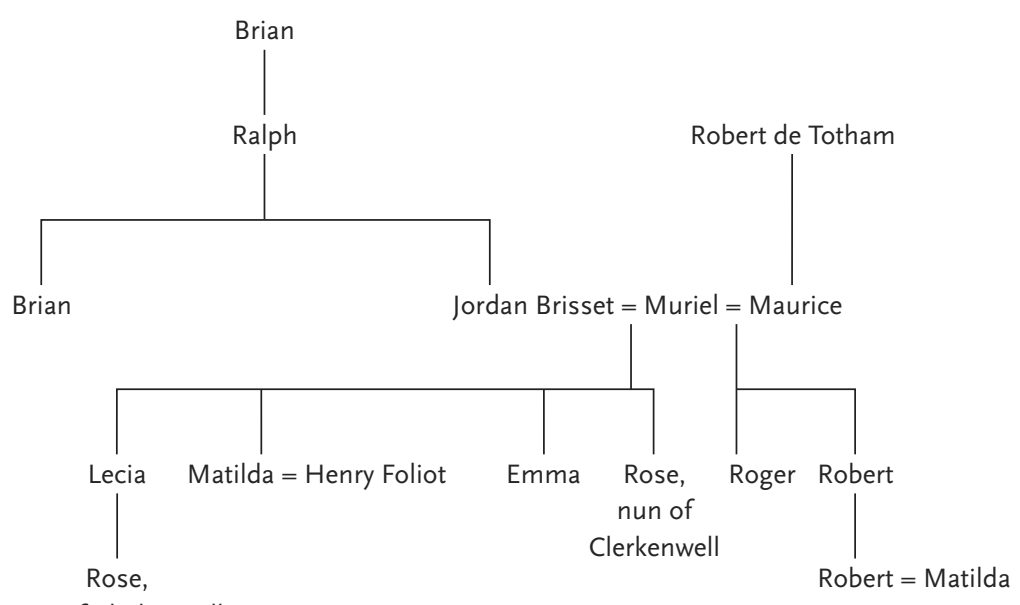

nun of Clerkenwell

FIGURE 2 The genealogy of Muriel de Munteni

ten witnesses, including Muriel, who is called domina donationis. ${ }^{7}$ The use of the term suggests that the scribe who compiled/transcribed the charter sought a way to describe her key role as patron and benefactor, and suggests that the nunnery, although founded by Jordan and Muriel conjointly, may have been her initiative. ${ }^{8}$ In the same period they also made arrangements with Clerkenwell for their daughter's entry as a nun there. The charter's witness list includes Michael Capra and Roesia, his wife, who is probably Roesia the daughter of Muriel and Jordan, who later became a nun at Clerkenwell. ${ }^{9}$

Muriel de Munteni also used her influence to secure additional gifts to Clerkenwell during her second marriage. In a charter of 1176-79 she and Maurice de Totham (d. before 1196) conjointly granted various rights in the land they held of the bishop of London, a charter which was witnessed by Robert and Michael de Munteni and Roger, son of Maurice. ${ }^{10}$ Muriel also witnessed a grant made by Maurice in $1181-86$, as did her daughter Lecia, as well as Roger and John, the sons of Maurice, and Michael de Munteni. ${ }^{11}$ Maurice also made three other donations to Clerkenwell of land near Tottenham. ${ }^{12} \mathrm{He}$ also acted as a witness to grants made by family members and undertenants connected with the de Munteni fee. ${ }^{13}$ This is important because it indicates that he patronised the foundation of his wife's previous husband, which shows beyond doubt that he was influenced by Muriel in the direction of his religious patronage. 
Muriel's concern for the welfare of her daughter was expressed through the careful arrangements she made to ensure that Roesia was properly clothed and fed once she entered the convent. In 1175-79 Muriel gave rents to Clerkenwell from land which was of her marriage portion and stipulated that the money was to be in effect Roesia's clothing allowance. ${ }^{14}$ In total there are eight charters in Muriel's name. ${ }^{15}$ Lecia, the daughter of Muriel and her husband, Henry Foliot, in 1193 to Michaelmas 1196 confirmed to Clerkenwell the service of Solomon of Stepney, for which they received eight marks from the nuns of Clerkenwell for the quitclaim. ${ }^{16}$ By the address clause Henry and Lecia greet 'all of Christ's faithful', and thenceforward all the verbs are in the plural: they concessisse et dedisse, and they made their affidavit conjointly. The closing protocol contains the phrase et sigillorum nostrorum appositione communimus, which suggests that Henry and Lecia strengthened the charter by their seals: there were separate sealing clauses for Henry and Lecia, and another for Muriel. The sealing clause for Muriel suggests that she gave her consent. Muriel also witnessed a charter of Lecia and her husband before 1182 and one of Emma and her husband, Reginald de Ginges, prior to 1186; further, she witnessed a charter by an undertenant before March 1190. ${ }^{17}$ There are seven charters in her name from her second widowhood, the period $1193-96 .{ }^{18}$ Muriel was probably acting to secure her gifts in her old age, and was thus seeking to ensure the security of her favourite foundation after her death.

Muriel de Munteni is a truly remarkable example of female influence expressed through two marriages and widowhood. The ways that she was involved in religious benefaction shows how noblewomen could participate in land transfers as witnesses, alienors and confirmers despite changes in the female life cycle. Without doubt Muriel's position as an heiress underpinned her power as a secular landholder, which therefore facilitated her participation in grants to the religious house that she had played a key role in founding. Her commitment was crystallised when she took care to provide for her daughter Roesia, who became a nun there. There is no evidence that Muriel retired to the convent, although it is of course possible.

Lecia's attachment to her sister, the nun Roesia, is evident in the cartulary. Her concern for her sister's welfare is shown $c$. 1178 when, as widow, Lecia granted her sister land held of her by an undertenant to pay for her sister's clothing. ${ }^{19}$ The land was to revert to Lecia or her heirs upon the former's death. Her mother Muriel had made a grant of $5 s$ rent for clothing, but in Roesia's grant the rent was to remain with the nuns after Roesia's death. ${ }^{20}$ It was thus the female members of the 
family which maintained close connections with the priory. Indeed, Lecia named her daughter after her sister, showing the close relationship between the two sisters. This close relationship between female kin of the de Munteni family was further emphasised when Lecia, with her husband, Henry Foliot, before Michaelmas 1196 gave land in order that their daughter Roesia could become a nun, and Lecia also at her will quando voluero mutare vitam meam ut recipiar ad habitum monialem in domo de Clerek[enwelle]. Henry Foliot and Lecia conjointly sealed the charter to ensure their gift, the sealing clause neatly summing up their joint responsibility to secure the gift through a warranty clause. They acted versus omnes homines et feminas and also announced that presentis carte attestatione et sigillorum nostrorum appositione communimus. ${ }^{21}$ The conjoint sealing clause stressed equal authority. It is unclear when or whether Lecia entered the priory, but it seems likely that she did, given her support and patronage, the fact that her sister was already there and the arrangements that she made for her daughter. Lecia was involved with donations and gifts to Clerkenwell for over twenty years during the period 1176-98 in various capacities which include co-alienor, grantor and witness. ${ }^{22}$ There are eight charters of Lecia and her husband in favour of Clerkenwell, one in 1176-October 1186, three in the 1180s and four in the $1190{ }^{23} .^{23}$ In return for their gift to Clerkenwell in 1181-89 they received twenty-five marks and for their grant of 1182 they received two marks and one mark respectively. Henry, Lecia and Muriel received eight marks for a quitclaim they made between $1193-96 .{ }^{24}$ As a wife she granted two charters as sole alienor, one $c$. 1178, which was to the benefit of her sister Rohais, and one in c. 1178/79 in favour of Mabel, the wife of Stephen Barre. ${ }^{25}$ Circa 1197 in viduitate mea Lecia confirmed all previous gifts made by her husband, father and mother as well as those by her sisters Emma and Matilda. In return the nuns gave her ten marks. ${ }^{26}$ Out of twenty-four charters which involve Lecia as grantor, witness or as lord of the lands in question, Lecia received countergifts on seven occasions worth in total over forty-four marks, $2 s$, one bezant and a pair of sandals. ${ }^{27}$

Landholders exploited the value of their land when they accepted relief payments such as those received in gersum for enfeoffment in return for specific rents or services. In a grant by Lecia of Ravenildescroft in Newington to Emma, daughter of Wimund, the condition of service was that Emma should render two headdresses (coifas) per year, saving service to the king for the defensio of eight acres. For this concession Emma gave Lecia some sandals. ${ }^{28}$ This was a confirmation of her mother's gift to Emma when Muriel had received a peplum - a robe, veil

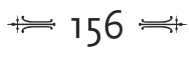


or possibly a wimple. ${ }^{29}$ Further Lecia stipulated that Emma's sister, another Emma, should be her heir, rendering $2 s$ yearly, saving service to the king.

Circa 1175 Robert de Munteni gave 'his man' Ailward land worth 3s per year which was given for the sake of his soul and that of his wife, Matilda, who witnessed the charter. ${ }^{30}$ Matilda also, with her husband, Robert, witnessed a charter of Michael Capra and his wife, Rohais, c. $1156-62 .{ }^{31}$ Emma de Munteni, who married Reginald de Ginges, like Lecia and Matilda, her sisters, participated in religious benefaction of Clerkenwell. The cartulary records six acta of Reginald and Emma concerning various grants and agreements related to lands held by Clerkenwell. ${ }^{32}$ In a notification charter Emma and her husband informed the bishop of London that they had confirmed a grant by Maurice de Totham, Emma's stepfather, of the parochial rights in the bishopric of London belonging to their fee. ${ }^{33}$ Like her sister Lecia, Emma participated in the religious patronage of Clerkenwell as a wife, and her position as co-heiress facilitated her participation in religious benefaction when, for example, before 1182 she witnessed a tenant's charter. $^{34}$ The founder's daughters thus maintained the family connection with the nunnery. Undertenants of the de Munteni family also donated land: for example, Robert Brito de Aldwych made a series of grants to Clerkenwell. ${ }^{35}$ These entailed the procuration of a series of confirmation charters issued by Robert's son Roger, Reginald de Ginges, Emma, his wife, Henry Foliot and Lecia de Munteni. ${ }^{36}$ Robert Brito de Alwych was thus an undertenant of the Muntenis, and to secure their gift the nuns pursued every possible avenue of confirmation, recording such from the heir (Roger de Brito) of the tenant, and the co-heiresses/co-lords Lecia and Emma de Munteni and their husbands. The nuns were obviously anxious to secure their grants, and it is interesting that the only individuals who are not recorded as receiving countergifts were Emma and her husband. This suggests that Lecia was the elder co-heiress, with greater right to the land in question and this position enabled her to exploit the revenue which could be generated when confirmation acta were granted. This accounts for the confirmation charter issued by Henry Foliot and Lecia in the period $1176-$ October 1186, when they confirmed a gift of five acres to the nuns by Emma and Reginald de Ginges. ${ }^{37}$

As wives Muriel, Lecia, Emma and Matilda de Munteni participated in actions to further the interests of the nunnery, and their power to do so rested on their position as heiresses. As widows Lecia and Muriel were involved in the patronage of the nunnery. Such family 
group action is also apparent in the charter evidence relating to the Capra family. Alice Capra, wife of William Capra, and one of her nieces became nuns at Clerkenwell before July $1176 .^{38}$ This charter was cogranted by her three daughters, Agnes, Alice and Constance, and their husbands for the soul of William Capra and Alice, who had become a nun there. Agnes, Alice and Constance were co-heiresses of the manor of Langford, Essex, from which the rent of $30 s$ was granted. ${ }^{39}$ The participation of the women of the Capra family as wives was related to their position as heiresses. Thus as both wives and widows in the specific context of religious patronage women pursued their own policies and initiatives.

The ways that the de Munteni family acted to maintain family links through the conduit of religious patronage are not unusual. The problem with identifying such patterns of behaviour within families from the lower ranks of the nobility lies with the survival rate of documents. There are examples of noblewomen making benefactions for their family and kin. In 1144-59 Beatrice de Chevrecurt with her brother and nephews, Jordan and Richard, conjointly gave the town of Barnsley to Pontefract. ${ }^{40}$ In return the monks agreed to appoint a monk for their mother, one for Beatrice and one for Ralph to pray for them. By this agreement, Beatrice's nephew Ralph, the son of Ralph, her brother, received a monk's tunic and boots yearly from the abbey. Beatrice was therefore actively participating in the context of the religious patronage of her natal family and by so doing publicly confirmed her spiritual affiliation to her lineage. Juetta and William de Arches gave six carucates to Nun Monkton, which they founded for their daughter, Matilda, to be a nun there in 1147-53. Matilda became prioress, and her sister Juetta gave the town of Stainton (Co. Durham) and alms to the priory. ${ }^{41}$

The importance of the female life cycle in defining the place of women in society can be tested with an examination of the evidence relating to unmarried women. There are very few examples of young unmarried women granting charters, and thus maidenhood may have disbarred young women from acting as religious patrons in their own right. Nevertheless there is evidence, albeit fragmentary and rare, to show that young noblewomen could participate in religious patronage, in their own right or as witnesses to their parents' gifts. Sibyl lady of Wilfrechston gave land by hereditary right, and placed the Gospels on the altar as token of her gift. She did this before her marriage. ${ }^{42}$ In 1165 Philippa de Rosel, a patron of Notre-Dame d'Ardennes, near Caen, gave land as a maiden, and she was an important benefactor throughout all three of her subsequent marriages. ${ }^{43} \mathrm{~A}$ member of the 
urban bourgeoisie, Preciosa, the daughter of Master Benedict granted lands by charter in 1200-15 when she was fourteen years old. ${ }^{44}$ All three women were heiresses, again indicating that it was the relationship between landholder and land that affected ways that women could participate in land transfers.

Women's power to grant land in the context of religious patronage gave them a public role which was considerably magnified if the woman was an heiress or a widow. Women generally did not hold formal public office: such roles as chamberlain, mayor, juror, sheriff or other administrative roles, as they developed, were gendered male in twelfth-century England. There is, however, evidence to suggest that at least one noble household, that of Matilda de Percy countess of Warwick, had a female official employed as a chamberlain. The language used within the charter which suggests that a female chamberlainship existed is precise. Circa 1184-99 Matilda granted to Juliane camerarie mee sorori Roberti camerarii mei various lands in Spofforth (Yorkshire) to be held in feodo et hereditate libere quiete et solute.$^{45}$ Juliana's brother, described as Countess Matilda's chamberlain, had previously received these lands from Adam, son of Copsi, confirmed by Matilda de Percy in $1175-c .1184 .{ }^{46}$ It is possible that the lands which Countess Matilda conveyed by charter to Juliana devolved to her by right of inheritance as her brother's heir. It is unclear whether this position of chamberlain in Matilda de Percy's household was heritable and linked to specific land. However, the charter suggests that she was a household official prior to his death and it is possible that they shared responsibilities. ${ }^{47}$ This is indicative that positions of office in a noble household of a powerful dowager countess like Matilda de Percy were perhaps kindred-linked, a familial concern and heritable to the extent that women could perform such roles on occasion. Matilda de Percy also confirmed to the Benedictine nunnery of Stainfield a grant of twenty acres by Juliana, camerarie mee. ${ }^{48}$ It is significant that Juliana did not witness Matilda's charters in any official capacity as chamberlain, unlike her brother and her husband, Nigel de Plumpton. ${ }^{49} \mathrm{Her}$ office as chamberlain may have been familial and heritable but it was also personal and linked with the patronage and power of Matilda de Percy. Matilda probably chose to have a female official and this may reflect personal connections between Juliana and Matilda de Percy. The exercise of public duties may well have been a function of the wife of a sheriff, as the discussion of Bertha de Glanville, who received affidations from women, has previously suggested, and indeed the witnessing and sealing of documents by women also suggest recognised roles and duties by wives and widows. 
There are other examples of aristocratic and noblewomen retaining female household servants and followers, but few examples of women giving land to female servants/retainers, and these are mostly granted by women of comital or royal status. This suggests that economic resources that underpinned social status were important in enabling women to make secular grants to female servants. Eleanor of Aquitaine granted Amicia Pautos her servant the manor of Wintreslewe, which enabled Amicia to retire to a convent as a nun. ${ }^{50}$ In the late eleventh century Queen Matilda had given Gundreda de Warenne a mansio named Carlton. ${ }^{51}$ Hawise countess of Aumâle gave land to her wet nurse as a reward for her service in the early thirteenth century. ${ }^{52}$ In the midtwelfth Amice countess of Leicester gave her lady-in-waiting $4 s$ annually on her marriage to a retainer of the earl. ${ }^{53}$ In 1190-1210 Alice Basset, with the consent of her son Hugh and her daughters Iseult and Helen, gave her land at Patrick Pool, York, to Thomas de Langwath to be held by rendering a pound of pepper annually pro labore suo exhibito circa doctrinam predicte Hugonis filii mee. ${ }^{54}$ In the early thirteenth century Agnes de Condet willed various valuable gold rings to her sons and daughters, sums of money to her maidservants, including a scarlet cloak and linen cloth, as well as gifts to servants, friends and religious houses of various sums of money. ${ }^{55}$

There is evidence that women could hold public office if they had a claim through patrilineal hereditary right. Nichola de la Haye was the eldest daughter and co-heir of Richard de la Haye, hereditary constable of Lincoln Castle and sheriff of Lincolnshire, and his wife, Matilda, the daughter of William of Vernon. She was married twice, firstly to William of Erneis and subsequently, before 1185, to Gerard de Camville, passing the office of constable to each of her husbands. ${ }^{56}$ She was actively involved in the process by which her inheritance passed to her husbands; for example, in August 1189 she and Gerard de Camville had crossed to Barfleur to obtain a charter confirming her inheritance from King Richard. The charter confirmed to both Gerard and Nichola her inheritance and lands and the constableship of Lincoln Castle, together with lands at Poupeville and Varreville in the east Cotentin. ${ }^{57}$ Nichola was twice besieged at Lincoln Castle, once in 1191 with her second husband, Gerard de Camville, and again in 1217 as a widow after his death. ${ }^{58}$ In 1194 she accounted for the sum of 300 marks to marry her daughter, Matilda, according to her will, excepting one of the king's enemies. ${ }^{59}$ She continued to account for this debt until $1212 .{ }^{60}$ She had renegotiated the amount in 1200, and in 1212 she still owed $\mathfrak{E}_{20}$, forty marks and one palfrey. ${ }^{61}$ As a widow she held the manor of Swaton in Lincolnshire,

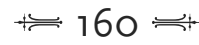


which was worth $\mathfrak{E}_{20}$ in 1185 and had been held by her mother as dower before her. ${ }^{62}$ In 1217, probably during the siege of Lincoln, Nichola, as castellan, and Geoffrey de Celand issued letters of protection to the church of Lincoln, the deans and canons and their households. ${ }^{63}$ There is no doubt that Nichola was a significant individual who held the office of castellan in her widowhood in her own right. ${ }^{64}$

This chapter began with a detailed study of de Munteni family grants to the nunnery of St Mary's, Clerkenwell, to show how charter evidence can be used to discuss the ways in which in a specific locality women of the lesser nobility maintained family contacts and networks of association through their religious patronage. This suggested that such women did so in their multiple identities as wives, widows, sisters, aunts, mothers and daughters, participating in land transfers as grantors, co-grantors and witnesses. These patterns of activity are similar to those of women from the higher nobility. As the discussion of, for example, Juliana de Plumpton and Nichola de la Haye showed, women of the lesser nobility occasionally held offices which were normally the preserve of men. Such examples, however, are rare and confirm that in general women did not hold office in formal ways. Yet the distinctions between formal public office holding and public roles are hard to define, and to draw them does little justice to the ways that women exerted power and influence. Powerful countesses and women of the lesser nobility such as those of the de Munteni family were able to enact policies and strategies irrespective of their exclusion from formal positions of office, and this is the key to understanding the power of twelfth-century women. Although the evidence discussed has been inevitably somewhat limited, it suggests that we should expect such patterns of activity to be general among twelfth-century noblewomen, whatever their social status.

\section{Notes}

1 Chester Charters, no. 194, and see nn. 199-200.

2 John Rylands University Library, Manchester, Rylands Charter, no. 1276.

3 Ibid., no. 1277.

4 VCH Middlesex, 1. 170, which states that Clerkenwell was founded by Jordan and his wife, Muriel, based on a confirmation charter of Henry II of c. 1176-78. Yet although she was associated with later grants with her husband and gave gifts of her own, it seems that the initial endowment was made by Jordan, possibly at Muriel's instigation. J. H. Round, 'The foundation of the priories of St Mary and St John, Clerkenwell', Archaeologia, 56 (1899), 225-6; S. Thompson, Women Religious: The Founding of English Nunneries after the Norman Conquest (Oxford: Clarendon Press, 1991), pp. 189-90. 
5 Matilda countess of Warwick in the 118 os took action on behalf of her father's foundation: see pp. 70-1. Lucy countess of Chester continued to patronise Stixwould through her three marriages: see pp. 60-1. So did Philippa de Rosel in the latter half of the twelfth century: see p. 158 .

6 Clerkenwell Cartulary, nos 2, 6, 9-10 (royal confirmations by Henry II and Richard of various grants, including those of the de Munteni family); as co-grantor with her first husband: nos 43, 74; as co-grantor with second husband: no. 53; as grantor: nos $64,73,81,84-6,90,109$, as a witness: no. 48 (grant of second husband), 79 (grant of younger daughter and son-in-law), 98 (elder daughter and son-in-law), 108 (charter of tenant); consent: no. 82, mentioned in text: nos 65, 80, 328, 324 (same as 328$)$.

7 Ibid., no. 43.

8 Thompson, Women Religious, p. 177.

9 Clerkenwell Cartulary, no. 74.

10 Ibid., no. 52.

11 Ibid., no. 48.

12 Ibid., nos 49-51.

13 Ibid., nos 92, 97, 113, 139, 149, 289.

14 Ibid., no. 90.

15 Ibid., nos 64, 73, 81, 84-6, 90, 109.

16 Ibid., no. 82.

17 Ibid., nos 48, 79, 98.

18 Ibid., nos 64, 73, 81, 85-6, 90, 109.

19 Ibid., no. 44 .

20 Ibid., no. 90.

21 Ibid., no. 72.

22 Ibid., nos 39, 61-2, 72, 80, 82, 87, 98 (co-grantor with husband), 44-5, 63, 65, 83, 328 (grantor), 48, 79, 90, 108 (witness), 73 (recipient), 81 (recipient of countergift), 64 (mentioned in mother's charter, which confirmed her grant, no. 63); 304 (mentioned in tenant's charter), 334 (same as no. 328 ).

23 Ibid., 1176-86: no. 39; 1180s: nos 80, 87, 98; 119os: nos 61-2, 72, 82.

24 Ibid., no. 82: Pro hac autem concessione et donatione et hac quieta clamatia dederunt predicte nobis predictis Henrico et Lucie et Muriele octo marcas argenti.

25 Ibid., nos 44 (c. 1178); 45 (1178/9).

26 Ibid., no. 83.

27 Ibid., nos 65 (a confirmation of 73), 80-3, 98, 328.

28 Ibid., no. 65.

29 Ibid., no. 73.

31 Ibid., no. 75.

32 Ibid., no. 302.

33 Ibid., nos 54-5, 79, 88, 97, 110.

34 Ibid., no. 54, confirming Maurice's grant (see nn. 11-12 above).

35 Ibid., no. 95.

36 The nuns paid him five marks and his son $20 s$ and, in another charter recording the same grant, ten marks; for another grant the nuns paid ten silver marks: ibid., nos $91-3$. 
Ibid., no. 64 C. W. Foster (Lincoln Record Society, 27, 1931), pp. 293-5. This is a fascinating insight into the material culture of a woman at the turn of the twelfth and early thirteenth centuries, and compares with the bequests made by Queen Joan of Sicily, the daughter of King John, in 1199, when she made a similar mixture of gifts to family, friends, servants and religious benefactions in her will: $C D F$, no. 1105.

$56 H K F, 3.56$.

57 Ancient Charters, no. 55.

58 See above, pp. 22-5, for a discussion of the portrayal of Nichola in the context of a discussion of the portrayal of women in chronicles and narratives generally.

Ibid., nos 91, 93 (charter witness list includes Aubrey de Vere earl of Oxford and Countess Agnes, his wife), 95-8.

1bid, , 0.39

HKF, 3. 17; Mon. Ang., 4. 85; VCH Middlesex, 1. 172.

$E Y C, 3$. no. 1771.

, 1. no. 535 and nn.

CDF, no. 517; confirmed by Ranulf (III) earl of Chester, Chester Charters, no. 319 .

EYC, 11. no. 63. H. M. Thomas, 'An upwardly mobile medieval woman: Juliana of Warwick', Medieval Prosopography, 18 (1997), 109-21, who discusses the translation of camerarie and suggests that it was a female equivalent of male chamberlain camerarius (pp. 111-12).

Thomas, 'Upwardly mobile medieval woman', pp. 112-13.

EYC, 11. no. 59.

Ibid., no. 38 (joint gift of Matilda and her husband, William earl of Warwick); Matilda $E Y C$, 11. no. 63 and nn. 63-4. Juliana was the daughter of Richard de Warwick (d. 1205); she married Nigel de Plumpton as his second wife. She had dower in Plumpton, Grassington, Idle and Ribston: Plumpton Correspondence: A Series of Letters, Chiefly Domestick, Written in the Reigns of Edward IV, Richard III, Henry VII, and Henry VIII, ed. T. Stapleton (Camden Society, old ser., 4, 1839), p. xvi. Juliana had a sister Sarra who married Gilbert de Beningworth and then Simon de Hauton. HKF, 2. 134-5, 180; Chester Charters, notes to no. 296.

$C D F$, no. 1091.

HKF, 3. 309. Gundreda d. 27 May 1085: CP, 12(1). 494.

Humberside County Record Office, Chichester-Constable Deeds, DDCC/135/1 (DBC).

D. Crouch, The Beaumont Twins: The Roots and Branches of Power in the Twelfth Century (Cambridge: Cambridge University Press, 1986), p. 157 n. Service in a countess's household could be one way in which working women earned a living and found a marriage partner.

EYC, 1. no. 295.

P.R. 6 Richard I, p. 119.

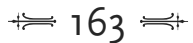


60 She appears in the Pipe Rolls successively: P.R. 8 Richard I, p. 237, where she owed $\mathfrak{E}_{94} 6 s$ 8d; P.R. 9 Richard I, p. 100 ( $\{946 s$ 8d); P.R. 10 Richard I, pp. 50 ( 63 (fifty marks); P.R. 1 John, p. 136 (£20).

61 P.R. 3 John, pp. 4, 290; P.R. 14 John, p. 103.

$62 R D$, p. 12; Rotuli Hundredorum, I, 309.

63 The Registrum Antiquissimum of the Cathedral Church of Lincoln: Volume II, ed. C. W. Foster (Lincoln Record Society, 28, 1933), pp. 23-4, no. 337.

64 In 1221 she granted various lands to Peter the Woadseller; in return he gave her $\mathfrak{E}_{20}$ and a pound of wax annually: The Registrum Antiquissimum of the Cathedral Church of Lincoln: Volume VIII, ed. K. Major (Lincoln Record Society, 51, 1958), no. 2297. Charter no. 2298 shows that John, son of Peter, sold the land and in the process 'handed over the charter of lady Nichola'. 